\title{
The Polish Translation of Chapter XX of the Fourth Book of Institutio Christianae religionis of John Calvin
}

One of important, and still insufficiently explained problems in studies on the Polish Reformation is the cause of popularity of its reformed, Calvinist current among the nobility of the Crown and Lithuania in the mid-sixteenth century. Numerous scholars believed that the reformed ecclesiology, which gave the authority over a congregation to the faithful, as well as the religious appreciation of the ideology of the class freedom by Calvin must have been particularly attractive for the Polish-Lithuanian-Ruthenian nobility under Sigismund Augustus in the first phase of open Reformation in Poland and the Grand Duchy of Lithuania, which coincided with the nobles' executionist movement. It was even hypothesised that certain phrasings in the work of the most eminent political author of the time, Andrzej Frycz Modrzewski, Commentatorium de Republica emenanda libri V (1554) are taken from Calvin's Institutio de Christiana religionis, and specifically from its 1543 edition, where the author included a commendation of elective, or even republican authority. ${ }^{1}$

It can be proven also that it was the ideological potential of the theological and political ideas of Calvin interpreted by his successors, including French and German Monarchomachs, that made the Evangelical-reformed political theology so attractive for classes that fought for the political domination in the second half of the sixteenth century,

1 W. Sobieski, 'Król czy tyran? Idee rokoszowe a różnowiercy za czasów Zygmunta Augusta', Reformacja $w$ Polsce, 4, 1926, 13-16, pp. 1-14. 
and then defended the class liberties from monarchistic and absolutistic tendencies displayed by rulers at the turn of the sixteenth and the seventeenth centuries. The Calvinism functioned at that time as an ideology in the Central Europe - it provided noble and bourgeois defenders of class liberties in Bohemia, Moravia and Hungary and even Austria, ${ }^{2}$ and perhaps also in the Polish-Lithuanian Commonwealth with a theological and religious justification.

Although, as proven by Leszek Jarmiński in his well documented monograph, the Polish and Lithuanian Protestants did not set up a political party at the turn of the sixteenth and the seventeenth centuries, in contrast to Austrian, Czech and Hungarian Protestants, as well as reformed bourgeois elites of the Northern Netherlands or French aristocracy and Huguenot nobility, ${ }^{3}$ an earlier inspiration by not only theological, but also political ideas of Calvinism cannot be excluded. ${ }^{4}$

If we accept, however, that Calvin's ideas influenced the formation of religious and political views of the nobility, and particularly the Protestants of the Commonwealth, then it is surprising that only a few of his fundamental works have been translated into Polish and published in the sixteenth century. Estreicher's Bibliography lists only his Latin letters published in 1560's, mainly those aimed at Antitrinitarians; ${ }^{5}$ in 1558,

2 S. Bildheim, Calvinistische Staatstheorien. Historische Fallstudien zur Präsenz monarchomachischer Denkstrukturen im Mitteleuropa der Frühen Neuzeit, Frankfurt a.M., 2001; W. Schulze, 'Estates and the Problem of Resistance in Theory and Practice in the Sixteenth and Seventeenth Centuries', in Crown, Church and Estates. Central European Politics in the Sixteenth and Seventeenth Centuries, ed. by R.J.W. Evans and T.V. Thomas, New York, 1991, pp. 158-75; J. Bahlcke, 'Calvinism and Estate Liberation Movements in Bohemia and Hungary (1570-1620)', in The Reformation in Eastern and Central Europe, ed. by K. Maag, Aldershot, 1997, pp. 72-91; D.P. Daniel, 'Calvinism in Hungary. The Theological and Ecclesiastical Transition to the Reformed Faith', in Calvinism in Europe, 1540-1620, ed. by A. Pettegree, A. Duke, and G. Lewis, Cambridge, 1994, pp. 205-30; R. Pörtner, 'Gegenreformation und ständischer Legalismus in Innerösterreich, 1564-1628', Zeitschrift für Historische Forschung, 27, 2000, 4, pp. 499-542.

3 H.G. Koenigsberger, 'The Organization of Revolutionary Parties in France and the Netherlands during the Sixteenth Century', Journal of Modern History, 27, 1955, pp. 335-51; Polish translation: 'Partie rewolucyjne we Francji i Niderlandach w XVI w.', in Europa i świat w początkach epoki nowożytnej, Part 1: Spoteczeństwo, kultura, ekspansja, ed. by A. Mączak, Warsaw, 1991, pp. 206-25.

4 L. Jarmiński, Bez użycia sity. Dziatalność polityczna protestantów w Rzeczypospolitej u schytku XVI w., Warsaw, 1992, pp. 243-48.

5 T. Grabowski, 'Z dziejów literatury kalwińskiej na Litwie', offprint from Reformacja $w$ Polsce, 6, 1934; Estreicher, vol. 19. 
the translation of his Catechism was published, and it is not before 1599 and 1626 that two fragments of Calvin's opus magnum, that is, Institutio Christianae religionis, have been translated and published, discussing, respectively, the church-state relations ${ }^{6}$ and the doctrine of sacraments. ${ }^{7}$ Obviously, the Evangelical elites - mainly clergymen - used the works of the Genevan Reformer in their original editions. However, the small number of editions and translations confirms the thesis of the intellectual weakness of the nobles' Reformation in the Commonwealth, ${ }^{8}$ and as an explanation of the long gap between the publication of the Catechism and of the fragments of Catechism can be quoted the - reminded by Janusz Tazbir - view of Jakub Niemojewski, who wrote in 1580 that 'the whole theology $[\ldots]$ has almost palled on the people'?

However, a change must have occurred towards the end of the sixteenth century, as in 1599 and 1626 these two important fragments of Institutio have been published in Polish. The circumstances in which the second text - Nauka o sakramenciech swiętych - was published are quite well known. In 1624, the authorities of Jednota Litewska had the translation made by Jan Czyż. The quality of that text must have been doubtful, however, as during the council of Jednota in Vilnius clergymen were ordered to inspect the translation and it was assumed that a new translation will be necessary of this fragment - a crucial one in the context of the argument about the interpretation of the Eucharist. ${ }^{10}$ Two years later the text was published, as its translator, however Piotr Siestrzeńcewicz is recognised, which suggests that the work of Czyż had been disparaged. The council of Jednota Litewska, debating in 1626 in Vilnius, thanked the Field Lithuanian Hetman Krzysztof Radziwiłł for having funded the translation and asked Siestrzeńcewicz to translate the

6 O zwierzchności świeckiej porządne wedtug sznuru Pisma świętego opisanie. Zaraz o pożytkach y powinnościach urzędu iey. Z tacińskiego na polskie wiernie przettumaczone, [no place], 1599.

7 Nauka o sakramenciech swiętych Nowego testamentu. Wzięta z czwartych ksiag Institucij nabożenstwa krześcijańskiego Jana Kalwina, Lubcz, 1626.

8 J. Tazbir, 'Reformacja jako ruch umysłowy', in idem, Szlachta i teologowie. Studia $z$ dziejów polskiej kontrreformacji, Warsaw, 1987, pp. 31-52.

9 Ibid., p. 43.

10 Canon 17 of the council of Vilnius in 1624, Akta synodów prowincjalnych Jednoty Litewskiej 1611-1625, Vilnius, 1915, p. 88 (Monumenta Reformationis Polonicae et Lithuanicae, ser. IV, fasc. II); see Grabowski, op. cit. 
whole text of Institutio. ${ }^{11}$ That initiative should be probably associated with a campaign aimed at strengthening the church structures and the consciousness of the faithful, conducted by Calvinists in the Grand Duchy of Lithuania in 1620's and 1630's.

The 1599 edition of Chapter XX of the fourth book, published as O zwierzchności świeckiej porządne wedtug sznuru Pisma świętego opisanie [Of civil government, orderly, according to the Holy Scripture described], is a different matter. Circumstances in which the translation came into being remain unknown, although the work has been recorded not only by bibliographers, but also by historians. It has been noted by Janusz Tazbir, who mentioned, when discussing the social-political propaganda of the Counter-Reformation, that the translation was intended as a defence against charges that the Reformation shatters the natural social and political order and that it instigates rebellion against legitimate authorities. ${ }^{12}$ Apart from this, the translation was apparently of no interest for either historians of religious interrelations or for theologians. It was not discussed in the valuable study of the religious phraseology of modern Polish Calvinism, authored by Izabela Winiarska, although she mentions the edition of Nauka o sakramenciech swiętych [The doctrine of the holy sacraments]. ${ }^{13}$

After all, it is one of the most important theological and political works of that time; not only it aroused a huge interest in the sixteenth century, but it remains an object of research and discussion. Originally entitled $D e$ politica administratione, ${ }^{14}$ the text summarises Calvin's views about state and political authority. Following Saint Augustin, Calvin acknowledged the indispensability of the state, acting propter peccatum, i.e. to minimise the pitiful effects of the sinfulness of the human nature, side by side (though not

11 Akta i sprawy synodu prowincjonalnego wileńskiego 1626, Central Archives of Historical Records in Warsaw (AGAD), Radziwiłł Archive (AR) VIII, no. 713, p. 71. 12 J. Tazbir, 'Społeczno-polityczna propaganda kontrreformacji', in idem, Szlachta i teologowie..., op. cit., p. 89; see: idem, 'Społeczno-polityczna propaganda polskiej kontrreformacji', Euhemer. Przeglad Religioznawczy, 19, 1975, 1, pp. 75-89.

13 I. Winiarska, Stownictwo religijne polskiego kalwinizmu od XVI do XVIII wieku, Warsaw, 2004, p. 60.

14 The edition quoted here is Ioannis Calvini opera selecta, ed. by P. Barth and G. Niesel, vol. 5: Institutionis Christianae religionis 1559 librum IV. continens, Munich, 1936. Cf. J. Calvin, Unterricht in der christlichen Religion. Institutio Christianae Religionis, transl. and ed. by O. Weber, Neukirchen, 1997 (6th edn.), and J. Calvin, Institutes of the Christian Religion, transl. by H. Beveridge, vol. 2, Grand Rapids [s.a.]. 
on equal terms) with the church. ${ }^{15}$ The church needs a civil order, because peace is a base, upon which the Christian community can build its religious life. The secular authority is, therefore, needed as a guardian of peace: 'cuius usus non minor inter homines quam panis, aqua, solis et aeris'. ${ }^{16}$

More importantly, the political ideas that has been expressed in that text played in 1570's a crucial role in the development of the views on the limitations of lieges right to resist the state. Although Robert Kingdon, one of the most prominent contemporary experts in the field wrote that 'In development of Calvinist resistance theory, Calvin himself played a role which was seminal but not major. For the greatest political challenges to his movement developed after his death', ${ }^{17}$ it would be impossible to reconstruct the political context in which $O$ zwierzchności świeckiej was published in 1599, without knowing his opinion about ius resistentiae.

Calvin's political ideas are the more interesting that they are set in the context of the discussion on the beginnings of the parliamentary democracy. Since the nineteenth century, there is an ongoing debate, whether the origins of the European democracy are to be associated with the English political discussion epitomised by Thomas Hobbes and John Locke or with the, over a century earlier, Calvinism. Numerous historians, especially those active in the nineteenth and in the first half of the twentieth century (Max Weber and Ernst Troeltsch, as well as Émile Doumergue, the author of the monumental biography of the Genevan reformer) claimed that the origins of the representative democracy are to be found in the system preferred by the reformed churches, where it was the 'people', i.e. the body of full members of the community (which, in practice, meant fathers of families) who choose the congregation's authorities. It was claimed that the democracy of the reformed ecclesiology resulted from Calvin's opinions, as expressed in the Chapter XX of the fourth book of his Institutio. ${ }^{18}$ The influence of these opinions was quoted

15 Św. Augustyn, O państwie bożym. Przeciw poganom ksiag XXII, transl. and ed. by W. Kornatowski, vol. 2, Warsaw, 1977, Book XIX, Chapter 17; S. Jóźwiak, Państwo i Kościót w pismach św. Augustyna, Lublin, 2004, pp. 66-91; cf. B.B. Warfield, Calvin and Augustine, Philadelphia, 1956.

16 Ioannis Calvini opera selecta..., op. cit., vol. 5, pp. 473-74.

17 R. Kingdon, 'Calvinism and resistance theory, 1550-1580', in The Cambridge History of Political Thought, 1450-1700, ed. by J.H. Burns and M. Goldie, Cambridge, 1991, p. 193.

18 H. Baron, 'Calvinist republicanism and its historical roots', Church History, 8, 1939, pp. 30-41. 
to explain the success of the democracy in countries dominated by the Calvinism: Switzerland, Netherlands, England, Scotland, and above all in the British colonies in North America. Particularly in France, there was a longstanding conviction that the modern democracy has its roots in Calvin's works, ${ }^{19}$ and even when a more detailed research proved that this view is too simplistic, the belief in the contribution of Calvinism to the secular democracy remained, and it was only in the second half of the twentieth century that it has been questioned..$^{20}$ The longstanding discussion on this subject will not be quoted here, as it is sufficiently covered in the literature. ${ }^{21}$

The modern interpretation of Calvin's views about the state and citizens' duties is based on the works of Josef Bohatec and Marc-Eduard Chenevière. ${ }^{22}$ According to the latter scholar, Calvin - influenced by French experience - preferred a system of 'aristocratic' rule that would be moderated or controlled by a 'democratic' factor, where the terms 'aristocratic' and 'democratic' are understood as Aristotelean categories adjusted to the reality of the sixteenth century. ${ }^{23}$ Bohatec analysed, among others, the principle of mutua obligatio, presented by Calvin already in his commentary to the Epistle to Romans in $1539 .{ }^{24}$ It says that the authority and its subjects are linked by an obligation, the unifying force and guarantor is the God. If the authority violates the law, it will be responsible before the God, and the same concerns the subjects. ${ }^{25}$ It must be stressed, however, that the obligation should not be understood as a contract of a public and legal nature. This interpretation has been

19 É. Doumergue, Calvin, le fondateur des libertés modernes. Discours prononcé à la séance de rentrée de la Faculté de Montauban, le 17 novembre 1898, Montauban, 1898. 20 R.M. Kingdon, 'Calvinism and democracy. Some political implications of debates on French Reformed church government, 1562-1572', in Calvin and Calvinism. Sources of democracy?, ed. by R.M. Kingdon and R.D. Linder, Lexington, Mass., 1970, pp. 45-49. 21 Calvin and Calvinism..., op. cit.; H. Vahle, 'Calvinismus und Demokratie im Spiegel der Forschung', Archiv für Reformationsgeschichte, 66, 1975, pp. 182-212.

22 J. Bohatec, Calvins Lehre von Staat und Kirche mit besonderer Berücksichtigung des Organismusgedankens, Breslau, 1937; M.-E. Chenevière, La pensée politique de Calvin. Thèse droit Gèneve, Geneva, 1937.

23 Chenevière, op. cit., pp. 181-90. Cf. J.T. McNeill, 'Democratic elements in Calvin's thought', in Calvin and Calvinism..., op. cit., pp. 30-35.

24 J. Calvin, 'Commentaries on the Epistle to the Romans, Chapter XIII', in idem, On God and political duty, ed. by J.T. McNeill, New York, 1950, pp. 83-87.

25 Bildheim, op. cit., pp. 31-36. 
popularised much later, by the Monarchomachs, as mutua regis cum civibus pactio or even contractus populi cum principe. ${ }^{26}$

The obligation discussed by Calvin is of a religious nature, it s concluded before the God, and to violate it equals to offending Him. This is why subjects are obliged - if the authority violated the law of God - to offer a passive resistance, i.e. to refuse to carry out godless orders. An authority that acts openly against the God's law loses its legitimacy, and thus a refusal to submit to it is not a rebellion. ${ }^{27}$ Individuals, however, have no right to offer the active resistance, even when confronted with an evident tyranny, because 'non est in arbitrio populi constituere principes'. ${ }^{28}$ The subjects can only express their opposition, and then they must suffer the consequences - they should suffer and pray, firmly believing that the God's justice will finally prevail. ${ }^{29}$ It does not mean that the reformer ruled completely out an active resistance - there is no doubt, however, that in his opinion it was not an individual, but rather magistratus populares or magistratus inferiores, i.e. local authorities or class representatives acting within the legal frames that are obligated to curb royal libido dominandi. ${ }^{30}$

26 Bohatec, op. cit., pp. 64-75; M. Thompson and H. Höpfl, 'The history of contract as a motif in political thought', American Historical Review, 84, 1979, 4, pp. 919-44. 27 'Praelectiones in Danielem prophetam, vol. II', in Ioannis Calvini opera, vol. 41, ed. by E. Reuss, A. Erichson, and W. Baldensperger, Brunswick, 1889 (Corpus reformatorum), p. 25. See: Bildheim, op. cit., s. 31; Bohatec, op. cit., pp. 75-91.

28 'Praelectiones in Ieremiae prophetias et lamentationes, vol. III', in Ioannis Calvini opera quae supersunt omnia, vol. 39, ed. by E. Reuss, A. Erichson, and W. Baldensperger, Brunswick, 1889 (Corpus reformatorum), p. 158. See: W.J. Bouwsma, John Calvin. A sixteenth-century portrait, New York and Oxford, 1988, pp. 54-56.

29 J.W. Allen, A history of political thought in the sixteenth century, London, 1957, pp. 57-58; J. Bauer, Gott, Recht und weltliches Regiment im Werke Calvins, Bonn, 1965 (Schriften zur Rechtslehre und Politik, vol. 44) , p. 124.

30 Of crucial meaning here is $\$ 31$ of the Chapter XX in the 1559 edition: "Verum utcunque ipsa hominum facta censeantur, Dominus tamen per ea suum aeque opus exequebatur, quum sanguinaria Regum insolentium sceptra confringeret, ac intolerandas dominationes everteret. Audiant principes et terreantur. Nobis autem interim summopere cavendum, ne illam plenam venerandae maiestatis magistratuum authoritatem, quam Deus gravissimis edictis sanxit, etiamsi apud indignissimos resideat, et qui earn sua nequitia, quantum in se est, polluunt, spernamus aut violemus. Neque enim, si ultio Domini est effraenatae dominationis correctio, ideo protinus demandatam nobis arbitremur: quibus nullum aliud quam parendi et patiendi datum est mandatum. De privatis hominibus semper loquor. Nam siqui nunc sint populares magistratus ad moderandam Regum libidinem constituti (quales olim erant, qui Lacedaemoniis 
This very opinion, expressed literally in Chapter XX of the fourth book of Institutio, became the basis for the theories of the Protestant Monarchomachs and the theological foundation for the ideology of class resistance against centralist confessional tendencies of rulers. It was upon those theses that Teodor Beza, François Hotman and Phillippe Duplessis-Mornay - to mention only the most important theorists of the Huguenot school of the law of resistance - constructed their revolutionary theories since $1573 .{ }^{31}$ The publication of the Polish version of these deliberations in a period of a fierce struggle between the nobility's opposition and the court's party, accused of absolutistic tendencies in 1599, and thus between the Inquisitional Sejm in 1592 and the Zebrzydowski rebellion - could possibly be regarded as an Evangelical contribution to the Polish version of the law of resistance, ius de non praestanda oboedientia. Such assumption, however, would be against the opinion of Janusz Tazbir, quoted above. ${ }^{32}$

The Polish translation of the Calvin's text is worth of a closer inspection. The print has been recorded by Estreicher; ${ }^{33}$ on its title page there is no information concerning the place of publication and - interestingly - the author or the translator. Emphasised is, however, a quotation from the Epistle to Romans: 'A tak kto się przeciwia zwirzchności, Bożemu rządowi przeciwia się. A którzy się sprzeciwiają, sobie sami potępienie biorą [Whosoever therefore resisteth the power, resisteth the ordinance

Regibus oppositi erant Ephori: aut Romanis Consulibus Tribuni plebis: aut Atheniensium senatui Demarchi: et qua etiam forte potestate, ut nunc res habent, funguntur in singulis regnis tres ordines, quum primarios conventus peragunt), adeo illos ferrocienti Regum licentiae pro officio intercedere non veto, ut si Regibus impotenter grassantibus et humili plebeculae insultantibus conniveant, eorum dissimulationem nefaria perfidia non carere affirmem: quia populi libertatem, cuius se Dei ordinatione tutores positos norunt, fraudulenter produnt”, Ioannis Calvini opera selecta..., op. cit., vol. 5, p. 501. Cf. interpretations of this passus, e.g.: H. Baron, 'Calvinist republicanism and its historical roots (1939)', in Calvin and Calvinism..., op. cit., pp. 50-55; McNeill, 'Democratic elements...', op. cit., pp. 30-35; idem, 'Introduction', in J. Calvin, On God and political duty, ed. J.T. McNeill, New York, 1950, pp. XVIII-XIX; H. Höpfl, The Christian polity of John Calvin, Cambridge, 1985, pp. 152-71; W.J. Bouwsma, John Calvin. A sixteenth-century portrait, New York and Oxford, 1988, pp. 207-09.

31 W.S. Stankiewicz, Politics and religion in seventeenth century France. A study of political ideas from Monarchomachs to Bayle, as reflected in the toleration controversy, Berkeley and Los Angeles, 1960, p. 11.

32 Cf. note 14, and Tazbir, 'Reformacja jako ruch umysłowy...', op. cit., pp. 39-40.

33 Estreicher, XXX, 3, p. 187; I have consulted a copy kept in the Kórnik Library, Cim. Q 2665, through mf BN 2472. 
of God: and they that resist shall receive to themselves damnation]. It can be seen as a declaration of real intentions of the anonymous translator and editor, who mentions the author's name only in the dedication.

The lengthy (comprising almost 5 pages) dedication, that precedes the Calvin's text, offers much more possibilities of interpretation. The translator, who describes himself as a 'servant minimus in Christ' that is an Evangelical clergyman, wrote it to Lelów starosta Andrzej Szafraniec of Pieskowa Skała. He was a Calvinist, son of a prominent leader of Evangelicals of the Lesser Poland, former Sandomierz voivode Stanisław Szafraniec, deceased in 1598. It is well known that Szafraniec, after having retired from politics towards the end of 1580's, devoted himself to the religious activity, truing to strengthen the Calvinist orthodoxy within Jednota Małopolska, that was weakened as a result of Antitrinitarians' secession. ${ }^{34}$ Perhaps publishing of the translation of Calvin's text was a part of that campaign? The connection between this edition and the family of Szafraniec, which is confirmed by the dedication, suggests that the translator may have been one of clergymen of the Jednota Małopolska. Hypothetically, an obvious candidature would be Grzegorz of Żarnowiec (1528-1601), the pastor of the reformed congregation in Włoszczowa, neighbouring to the Szafraniec estate. He was the author of Postylla albo wyktady z ewanielijej niedzielne i świqt uroczystych przez caty rok [Postilla, or lectures on the Evangel for Sundays and festive days of the whole year], theological and polemic writings, and probably also a participant of the debate about the Warsaw Confederation. ${ }^{35}$

The contents of the dedication confirms the intention that has been signalled by the quotation on the title page. In the very first sentence, the translator of the Calvin's work says that Evangelicals are often regarded as opponents of the state, and then he adds: 'As some dared to say and to write that he who is not a Papist neither he is a royalist, that is he who does does not submit or obey to the Pope, does not submit to the king. ${ }^{36}$ Such voices propagate a bad opinion about Evangelicals 'among the brethren of a common nation, tongue and blood', i.e. the nobility,

34 H. Kowalska, 'Stanisław Szafraniec z Pieskowej Skały', Odrodzenie i Reformacja $w$ Polsce (hereinafter: OiRwP), 3, 1958, pp. 93-131; A. Kawecka-Gryczowa, 'Przyczynek do biografii Stanisława Szafrańca’, OiRwP, 17, 1972, pp. 189-90.

35 H. Kowalska, 'Grzegorz z Żarnowca', Polski Stownik Biograficzny (hereinafter: PSB), vol. 9, Wrocław et al., 1960, pp. 91-93; Winiarska, op. cit., p. 58.

36 zwierzchności, k. a II. 
instigating also against them 'the supreme authority', that is the king. ${ }^{37}$ To oppose this, dangerous to Protestants, tendency, 'I decided this small booklet $O$ zwirzchności świeckiej, written in Latin by an erudite and devout man, D. John Calvin, to translate into Polish, and to offer it to the general public' ${ }^{38}$

Then, quoting Calvin, he proves that Evangelicals, although they categorically refuse to acknowledge the Pope's authority, are Christ's servants, and therefore loyal subjects who respect authorities given to them by the God.

The last paragraph of the dedication seems, however, to allude to the situation of the Commonwealth. The translator says that all Evangelicals regret that many rulers 'bow before the Pope and kiss his feet', but he promptly breaks off this thread: 'About which one may speak at length; for now preferring brevity, I write nothing more. It is enough to say that it goes without any doubt that Evangelicals are always - and they want to remain - royalists, though Papists they neither are nor want to be' ${ }^{39}$ The issue of this ambiguity of intentions of the translator and editors will be discussed in due course.

First we should investigate, what induced the Calvininsts of the Lesser Poland to publish in 1599 the Calvin's text, as a declaration of their loyalty to the state. The view of their Catholic opponents has not changed towards the end of the sixteenth century - the Counterreformers have maintained since a long time that the religious diversity resulting from the Reformation leads inevitably to conflicts and weakening or even collapse of the natural political - and even social - order. Also in Poland, since the times of Stanisław Hozjusz and Stanisław Orzechowski, the argument, that tolerating or granting equal rights to heterodoxes leads to internal turmoil or overthrowing the monarchy, enjoyed a significant popularity in the Catholic propaganda. ${ }^{40}$

The ideology of the Counterreformation has not changed, but it is the social situation that changed in 1590 's. To the fore came slowly 'new Catholics' who, when confronted with heterodoxes, were easier to believe in Counterreformatory arguments and were ready to accept a conception of religious interrelations that proposed replacing the religious equality

37 Ibid.

38 Ibid, k. a III.

39 Ibid., k. A.

40 Tazbir, 'Społeczno-polityczna propaganda...', op. cit., p. 97. 
of the Warsaw Confederation with a tolerance, understood as a conditional consent to existence of minorities ${ }^{41}$. In practice, it was equal to the return of the concept of the Catholic denominational state which was unwaveringly promoted by Jesuits in their doctrine and propaganda. ${ }^{42}$

The most prominent promoter of this concept towards the end of the sixteenth century was Piotr Skarga and it is his writings and statements that were meant by the anonymous translator of Calvin's text when mentioning 'the only' who dared to say and write that Evangelicals - rejecting the authority of the Pope - cannot be regarded as loyal citizens. ${ }^{43}$ Skarga's opinions are well known - concerning relations between the state and the church, he adhered to the monarchist ideas of Jean Bodin. ${ }^{44} \mathrm{He}$ referred to monarchist ideas also in his anti-Protestant writings, beginning from his argument with an eminent Reformation theologian Andrzej Wolan in mid-1580's. ${ }^{45}$

It seems, however, that the open controversy over the civil loyalty of Evangelicals and their attitude towards the kingship did not start before the early 1590's, when Skarga has published - in a tense atmosphere after a Protestant church in Cracow having been burned - his Upominanie do ewanjelików [An admonition for Evangelicals] (Cracow 1592). ${ }^{46}$ In that text, he attacked openly the idea of the religious equality and the Warsaw Confederation, writing: 'that confederation is hostile and harmful to the Commonwealth, because where different faiths and confessions rule, there civil issues are differently understood, love and harmony are broken, and obedience and respect towards the authorities are lacking; without those, the Commonwealth weakens and dies'. ${ }^{47}$ To that, an anonymous

41 Idem, 'Kultura polska między renesansem a barokiem', in Przetom wieków XVI i XVII w literaturze i kulturze staropolskiej, ed. by B. Otwinowska and J. Pelc, Wrocław, 1984 (Studia Staropolskie, 52), pp. 22-25.

42 S. Obirek, Jezuici w Rzeczypospolitej Obojga Narodów w latach 1564-1668. Dziatalność religijna, spoteczno-kulturalna i polityczna, Cracow, 1996, pp. 45-51, 127-49.

43 See note 38.

44 J. Tazbir, Piotr Skarga. Szermierz kontrreformacji, Warsaw, 1978, pp. 168-69; S. Obirek, Wizja Kościoła i państwa w kazaniach ks. Piotra Skargi SJ, Cracow, 1994, pp. 199-210.

45 T. Grabowski, Piotr Skarga na tle katolickiej literatury religijnej w Polsce wieku XVI. 1536-1612, Cracow, 1913, p. 322.

46 [P. Skarga], 'Upominanie do ewanjelików i do wszystkich społem niekatolików iż o skażenie zborów krakowskich gniewać się i nic nowego i burzliwego zaczynać nie mają, ed. by M. Korolko, in M. Korolko, Klejnot swobodnego sumienia. Polemika wokót konfederacji warszawskiej $w$ latach 1573-1658, Warsaw, 1974, pp. 177-213.

47 Ibid., p. 183. 
author responded (not very convincingly) in Respons w porywcza dany na upominanie do ewanjelików [A response to the admonition for Evangelicals, impetuously given] (Toruń 1592): 'Neither the Confederation not the Evangelicals cannot be accused of a disrespect to authorities'. Then he says that it is Antitrinitarians who should excuse themselves for the reluctance to take civil offices. ${ }^{48}$

The next Skarga's assault on the Warsaw Confederation was even more fierce in accusing non-Catholics of harming interests of the Commonwealth. It was contained in the fourth part of Proces konfederacyjej [The process of the confederation], published in Cracow in 1595, entitled 'O szkodach i utratach, które herezyje chrześcijaństwu i policyjom abo Rzeczypospolitym przynoszą, [On harms and losses that are caused by heresies to the Christianity, the polity and the Commonwealth]. ${ }^{49}$ Not surprisingly, the response of the Evangelical polemicist, who was probably the above-mentioned Grzegorz of Żarnowiec, was even sharper. In a text entitled Obrona przeciw procesowi konfederacyjej [A defence against the process of the confederation], ${ }^{50}$ he briefly but firmly rejected Skarga's claim that the religious equality means allowing views hostile to the political order, and consequently a collapse of the monarchy, decency, and finally of the state itself. The Evangelical polemicist appealed to his reader's experience, saying that, since the Warsaw Confederation has been passed almost twenty years earlier, nothing that would oppose the political order of the Commonwealth was promoted, and the confederation itself was passed in order to elect kings and to defend the homeland without any feuds between followers of different faiths. Thus the religious equality is a guarantee, and not a threat to political peace. ${ }^{51}$

It is Skarga's Kazania sejmowe [Sejm Sermons], published in 1597, that could have been received as a real threat to the political rights of non-Catholics. The text, which is well known and repeatedly discussed, ${ }^{52}$ will not

48 'Respons w porywczą dany na upominanie do ewanjelików o zburzenie zboru krakowskiego i na przestrogę do katolików od kogoś uczynioną w roku 1592', ed. by Korolko, in idem, op. cit., pp. 232-33.

49 Korolko, op. cit., pp. 99-100.

50 'Obrona przeciw procesowi konfederacyjej teraz przed sejmem krakowskim wydanej, w którym jest jasne okazanie, że ewanjelicy konfederacyjej się upominając, nie żadnej inszej rzeczy żądają, jedno samego pokoju', ed. by Korolko, in idem, op. cit., pp. 261-92. 51 Ibid., pp. 276-77.

52 Grabowski, op. cit., pp. 399-446; S. Windakiewicz, Piotr Skarga, Cracow, 1925, pp. 158-85; S. Kot, 'Wstęp', in P. Skarga, Kazania sejmowe, ed. by S. Kot, Cracow, 1925 (BN); Tazbir, Piotr Skarga..., op. cit., pp. 136-63. 
be analysed here. Instead, we will focus on accusations of disrespect and hostility towards the kingship that are repeatedly made there against non-Catholics. These seem to form a coherent whole that was aimed at convincing Catholic readers that heterodoxes do not deserve being granted a political equality. ${ }^{53}$ It is already in the first sermon, Kazanie pierwsze na poczatku sejmu przy's. mszy sejmowej, that a thesis referring to the interregnum after the death of Stephen Báthory is found: 'Moreover, there proliferate in this kingdom very malevolent people [...] they incite rebellions and conspiracies wherever they can, by muttering against the divine office, making up calumnies, instigating unrest and novelties'. ${ }^{54}$ This concerns not only political opponents of the future Sigismund II but also Protestant political leaders. The religious unity is presented as a remedy for all feuds: 'Therefore do revive peace, harmony and unity among you. Get rid of heresies that are the mother of all discord.' 55

In the third sermon, Kazanie trzecie o drugiej chorobie Rzeczypospolitej, która jest z niezgody domowej, Skarga elaborated the thesis of heterodoxy as the source of all political differences in the Commonwealth: 'heresies and false faiths of all sorts, that try to corrupt the only true one, are the foremost cause of all those disagreements of yours' ${ }^{56}$ Then he states: 'The cause of the disagreements is not a small one: it is the inadequacy of respect towards the royal, given by the God, authority'. ${ }^{57}$ As a result, a connection between the religious equality and the disrespect to the royal authority is suggested, although the Protestants were only a small fraction - and not always the most important one - of the anti-court opposition.

The fourth sermmon, Kazanie czwarte o trzeciej chorobie Rzeczypospolitej, która jest naruszenie religiej katolickiej przez zarazę heretyckq as a whole is an attack on non-Catholics, whose very existence corrupts the state. His final conclusions contained Skarga in the fifth sermon, Kazanie piate ako katolicka wiara policyj i królestw szczęśliwie dochowywa, a heretyctwo je obala. He took it for granted that 'where there is no agreement concerning faith and things of God, there it cannot be also concerning secular things and polity', ${ }^{58}$ thus no political agreement is possible between followers

53 The edition used here is: P. Skarga, Kazania sejmowe, ed. by J. Tazbir and M. Korolko, Wrocław, 1984 (4th, extended edn., BN).

54 Ibid., pp. 10-11.

55 Ibid., p. 21.

56 Ibid., p. 73

57 Ibid., p. 74.

58 Ibid., p. 113. 
of different faiths. From these premises he concluded that 'The unity of the faith of God produces a single, harmonious kingdom, while heresies and different faiths divide kingdoms and by divisions lead them to disaster. ${ }^{59}$ Therefore, not only granting equal rights to heterodoxes, but even tolerating their existence poses a threat to the state. Which means that those who insist on granting equal rights and religious freedom do harm to the Commonwealth.

In final paragraphs of the fifth sermon, Skarga went as far as to reinterpret the Evangelical doctrine of predestination, stating that those who do not believe in a posthumous punishment for sins are devoid of any restraints in this life - also in the political sense: 'therefore heresies cannot make bonos cives'. ${ }^{0}$ Then he attributed - obviously in bad faith - Anabaptist views to the Protestants: 'There are such mistakes among Luthers and Evangelicals and they preach that officials, kings or starostas, living in a deadly sin, have no authority and must not be obeyed. What else could be worse than such evil doctrine of insubordination, rebellion and disturbance of universal peace?' ${ }^{21}$ Thus it is not only the religious equality that poses a threat to the Commonwealth, but also Protestant theologians who promote ideas inciting to anarchy and rebellions against the legitimate authorities. The ultimate goal of Skarga was not the abolition of religious equality that would be replaced with religious minorities being tolerated only by the Catholic state. His concept of the state, as elaborated in Kazania sejmowe, included the eradication of any denominational diversity, as heterodoxes posed not only a religious, but also a political threat to the Commonwealth.

Perhaps it was that radical attitude of Skarga in 1597 that induced the Evangelicals of Lesser Poland to present the political doctrine of John Calvin in Polish language. The authority of the Genevan reformer was quoted to dispel the doubts of those who - influenced by the false arguments of Kazania sejmowe, and that of Kazanie piate in particulartended to suspect Calvinists of hostility or disregard towards the state. Thus Calvin participated posthumously in the debate about the Warsaw Confederation - and speaking for its supporters, which would be a difficult decision for him during his lifetime - and provided his Polish followers with an excuse for their civil loyalty.

59 Ibid., p. 115.

60 Ibid., p. 123.

61 Ibid., p. 124. 
Concerning the mentioned above ambiguity in the dedication of O zwierzchności świeckiej, it must be noted that the fact of the Calvin's political doctrine having been published in 1599 could have a double meaning. Officially, it confirmed civil qualifications of Polish Calvinists, by emphasising 'loyalist' views of the most prominent theologian of that current in the Reformation. There is no doubt, however, that the Evangelical elites of Poland and Grand Duchy of Lithuania were aware of the latest developments in political and theological doctrine of Calvinism since 1573. Perhaps the Polish edition of the text, referred to by adherents of the theory of opposition to the royal authority, was intended also as a support for Protestant oppositionists, who protested against the enhancing of royal authority, as planned by Sigismund III and his circle, including rev. Skarga, who expressed it clearly in Kazania sejmowe.

Also certain modifications to the original Calvin's text may indicate that this was the case. The translator, who mainly remained faithful to the original, took the liberty of making some distinctive changes. Significantly, he removed the whole fifth paragraph of Chapter XX, where Calvin condemned objectors to the thesis of unlimited (because given by the God) royal authority, as proponents of anarchy. ${ }^{62}$ Moreover, the Polish text has been slightly abridged and adjusted to Polish reality. The most striking example of this can be found in the final part of the test, in paragraph 30 (paragraph 31 of the original), where conditions are discussed, that make it acceptable, to oppose a tyranny. 'For when popular magistrates have been appointed to curb the tyranny of kings (as they were among the Spartans, Romans and Athenians; and perhaps today there is something similar in primary diets), these should do their duty.' 63

62 "Excipiunt qui anarchiam inducere cuperent, quanvis olim rudi populo praefuerint Reges ac Iudices, hodie tarnen perfectioni, quam Christus cum Evangelio so attulit, minime qudrare servile illud gubernandi genus. In quo non suam modo inscitiam, sed Diabolicum fastum produnt, dum perfectionem sibi arrogant, cuius ne cetesima quidem pars in illis conspicitur", Ioannis Calvini opera selecta..., op. cit., vol. 5, pp. 475-76.

63 Page E III of the Polish edition; the original text: "Nam siqui nunc sint populares magistratus ad moderandam Regum libidinem constituti (quales olim erant, qui Lacedaemoniis Regibus oppositi erant Ephori: aut Romanis Consulibus Tribuni plebis: aut Atheniensium senatui Demarchi: et qua etiam forte potestate, ut nunc res habent, fubguntur in singulis regnic tres ordines, quum primarios conventus peragunt), adeo illos ferocienti Regum licentiae pro officio intercedere non veto, ut si Regibus impotenter grassantibus et hunili plebeculae insultatntibus conniveant, eorum dissimulationem 
By simplifying Calvin's argument, the translator confirmed the demand for a parliamentary control of the royal power in the Commonwealth.

The fact that the Evangelicals of Lesser Poland invoked the authority of John Calvin seems to prove the opinion expressed by Antoni Mączak, that 'the Polish nobility formulated its own concept of relationship between the state and the society, a specific view of the reason of nation, not necessarily identical with the reason of state - especially that embodied in the monarch and court'. ${ }^{64}$ This concerns, actually, not only evangelicals, who were - in a sense - condemned to resistance to the confessional ideas of the Sigismund's III court. Similar tendencies are visible also among Catholics. The Polish translation of the most famous political treatise of the time - De politicorum by Justus Lipsius - published in 1595 may be quoted as an example of this. It has been edited by Piotr Szczerbic, protégé of Jan Firley and Jan Zamoyski. The modifications introduced in the second edition of this work seem to indicate that the work has not been approved by court theologians. ${ }^{65}$ The views about the reason of state, developed by the nobility at the turn of the sixteenth and seventeenth centuries in opposition to the court ideology, referred to the currents in the European thought that were still disapproved by the Catholic church.

\section{Translated by Kamil O. Kuraszkiewicz}

First published as: 'Polski przekład XX rozdziału czwartej księgi Institutio Christianae religionis Jana Kalwina', Odrodzenie i Reformacja w Polsce, 50, 2006, pp. 101-13.

nefaria perfidia non carere affirmem: quia populi libertatem, cuius se Dei ordinatione tutores positos norunt, fraudulenter produnt", ibid., p. 501.

64 A. Mączak, 'Przełom stulecia przełomem losów Rzeczypospolitej?', in Przetom wieków..., op. cit., p. 46.

65 A. Kempfi, 'O tłumaczeniach Justusa Lipsiusa w piśmiennictwie staropolskim, Studia i Materiaty z Dziejów Nauki Polskiej, ser. A, fasc. 5, 1962, pp. 41-65; K. Lepszy, Firlej Jan z Dąbrowicy, PSB, vol. 7, Cracow, 1948-58, p. 7. 